\title{
The limits of reason: deliberation and phronesis of correctional officers
}

\author{
DéRIS Oliveira CaItano ${ }^{1}$ \\ Maurício SERva ${ }^{12}$ \\ ${ }^{1}$ Universidade Federal de Santa Catarina (UFSC) / Research Center on Organizations, Rationality, and DeVelopment, \\ FLORIANÓPOLIS - SC, BRAZIL \\ ${ }^{2}$ Universidade FEDERAL de SANTA CATARINA (UFSC) / COORDINATOR OF THE RESEARCH CENTER ON ORGANIZATIONS, RATIONALITY, AND \\ DEVELOPMENT (ORD/UFSC), FLORIANÓPOLIS - SC, BRAZIL
}

\begin{abstract}
The objective of this article was to verify in the experience of correctional officers, in a maximum security prison complex, elements that characterize a framework of phrónesis evidence. Phrónesis was described in Aristotelian philosophy as the virtue of a practical order that presupposes deliberation in critical situations, where the rationality of agents is limited by very specific contexts of action. The notion of phrónesis clear new perspectives to understand rationality in contingent circumstances of organizational praxis. This research was undertaken from a micro-sociological analysis of the practices of the agents in prison work. Data were collected from interviews and triangulated with field observation and document analysis. The results of the research illustrate evidence of the phrónesis from the analysis of the experience of the agents in the containment of organized crime actions inside the complex and in the effects produced in the management from that experience.
\end{abstract}

Keywords: Phrónesis. Rationality. Pragmatism. Penitentiary Agents.

\section{No limite da razão: o deliberar e a phrónesis no trabalho prisional}

\section{Resumo}

Este estudo teve por objetivo verificar na experiência dos agentes penitenciários, em um complexo prisional de segurança máxima, elementos que caracterizem um quadro de evidências da phrónesis. A phrónesis foi descrita na filosofia aristotélica como a virtude de ordem prática que pressupõe o deliberar em situações críticas, onde a racionalidade dos agentes é limitada por contextos muito específicos de ação. A noção de phrónesis ilumina novas perspectivas para compreender a racionalidade em circunstâncias contingenciais da práxis organizacional. Trata-se de pesquisa empreendida a partir de uma análise microssociológica das práticas dos agentes no trabalho prisional. Os dados foram coletados por meio de entrevistas e triangulados com observação em campo e análise de documentos. Os resultados desta pesquisa ilustram evidências da phrónesis a partir da análise da experiência dos agentes na contenção de ações do crime organizado no interior do complexo prisional e nos efeitos produzidos na gestão com base nessa experiência.

Palavras-chave: Phrónesis. Racionalidade. Pragmatismo. Agente penitenciário.

\section{Al límite de la razón: deliberación y frónesis en el trabajo de agentes penitenciarias}

\section{Resumen}

Este artículo tuvo por objetivo verificar en la experiencia de los agentes penitenciarios, en un complejo carcelario de seguridad máxima, elementos que caracterizan un cuadro de evidencias de la frónesis. La frónesis fue descrita en la filosofía aristotélica como la virtud de orden práctico que presupone el deliberar en situaciones críticas, donde la racionalidad de los agentes está limitada por contextos muy específicos de acción. La noción de frónesis ilumina nuevas perspectivas para comprender la racionalidad en circunstancias contingenciales de la praxis organizacional. Se trata de una investigación emprendida a partir de un análisis microsociológico de las prácticas de los agentes en el trabajo carcelario. Los datos fueron recolectados a partir de entrevistas y triangulados con observación en campo y análisis de documentos. Los resultados de la investigación ilustran evidencias de la frónesis a partir del análisis de la experiencia de los agentes en la contención de acciones del crimen organizado en el interior del complejo carcelario y en los efectos producidos en la gestión a partir de esa experiencia.

Palabras clave: Frónesis. Racionalidad. Pragmatismo. Agente penitenciario. 


\section{INTRODUCTION}

The increase of crime in recent years has caused the growth of the incarcerated population, overcrowding the prison system in Brazil (LIMA and BUENO, 2015) ${ }^{1}$. Prison overcrowding and lack of management in prison units, especially in large urban centers, favored the proliferation of criminal factions able to operate both inside and outside prisons (SALLA, 2006; ADORNO, 2008; DIAS, 2011; RANGEL and BICALHO, 2016).

Tackling the problems of public security and the reality inside prisons requires a broader perspective beyond legislation. These issues require the prisons' management capacity as a determining condition, to contain and track the activities of the organized crime. However, few studies have investigated management and the work within prisons based on the correctional officers' point of view.

Most of the scientific production on this topic emphasizes theoretical perspectives focused on inmate's concerns and dilemmas. The topic of management and work in prisons is addressed, however, in studies in the field of sociology by Adorno (2002), Salla (2006), Nunes Dias (2011), Bodê de Moraes (2013), Manso and Dias (2017). In the field of management, it is worth highlighting the research by Freitas (1985), Lemos, Mazzilli, and Klering (1998), Cabral and Lazzarini (2010), Cruz, Souza, and Batitucci (2013), and Rangel and Bicalho (2016).

It is assumed in this study that any attempt to reproduce a management model that guides public security actions toward containing the progress of organized crime (inside and outside prisons) will not produce the same effects in different contexts of action (local or regional). This predictive and normative inability of management to encompass all phenomena related to the subtleties of humanity configures the essentially contingent nature of work in prisons (BODÊ DE MORAES, 2005; GOFFMAN, 2008).

Management capacity, especially in this type of organization, is linked to the specific context of action and limited in its rationality by the depth and uncertainty of a context that cannot be reduced to rules (CLEGG, 2003, 2006). This bounded rationality, under which organizational theory is constituted, is what characterizes management as an example of phronesis (CLEGG, 2003; FLYVBJERG, 2001, 2006).

After the seminal studies by Guerreiro Ramos (1989), the focus in the current stage of the field of studies on rationality in organizations is to develop a deeper knowledge of rationality in action. Therefore, empirical research on rationality based on the perspective of action in organizations is particularly interesting, emphasizing, and problematizing management practices. This is the line of research, in our view, that will promote the advancement of this scientific field and bring an effective contribution to administration, which is, by definition, an applied social science. The use of the construct 'phronesis' in this study aims to privilege the practical dimension of rationality, avoiding an abstract and merely conceptual discussion. Thus, the study establishes the correspondence between philosophy and administration through a philosophy as an epistemology of practice, developed under the aegis of pragmatism (FREGA, 2006, 2012).

Phronesis (conceived as practical wisdom or prudence) is described in Aristotle's philosophy (1991) as an intellectual virtue of a practical nature capable of helping the man make the best decision in each context. For Aubenque (2008) and Maclntyre (1991), phronesis involves the ability to deliberate on the contextual factor, which is variable, contingent, and belongs to the field of practice, or how individuals act, guided by their reasons.

The contextual aspect differs from the universality of the phenomena, which characterizes the current paradigm of science. Therefore, phronesis represents an alternative for understanding phenomena in the social field (FLYVBJERG, 2001, 2006), in the field of management (KOIKE and MATTOS, 2001; CLEGG, 2003; KARAM, 2014; SANTOS, SERAFIM, PINHEIRO et al., 2018), or for the understanding of what Champy (2018) and Dubois (2018) described as "prudential" practices related to specific contexts of action, such as hospitals and prisons. At the heart of this concept is the ability to deliberate in an area of uncertainty, where there is no technical and scientific knowledge available (FLYVBJERG, 2001, 2006; DUBOIS, 2018).

${ }^{1}$ By 2030, Brazil may reach a prison population of 1.9 million adults, which requires building 5,780 prisons in 15 years (FBSP, 2015). 
This study does not intend to cover the entire field of management related to the prison system. It offers a pragmatic analysis of the management practices of correctional officers in the face of contingency situations. The research studied the Complexo Penitenciário de Segurança Máxima de São Pedro de Alcântara (COPE) (the largest maximum-security prison in the Brazilian state of Santa Catarina). - The institution gained notoriety nationwide after a series of critical events - an increase in the number of deaths due to the escalation of violence in the state and conflicts between criminal factions - occurred in 2012, 2013, and 2014. Also, it is renowned in the national prison system for some of its management practices.

Therefore, inspired by the Aristotelian concept of phronesis and considering the work in prison units as a complex activity, this study explores the following question:

- Do the management practices of certain correctional officers in critical situations - where the officers are called upon to deliberate on contingent demands - evidence phronesis?

The assumption adopted is that the work in prison units encompasses numerous practices and phenomena that highlight the choice and deliberation in the face of contingent events. These elements highly embody the bounded rationality in unusual situations (CLEGG, 2003), evidencing phronesis.

Understanding phronesis allows the theoretical debate of rationality studies to move through the subjective orbit for the verification of practices (GUERREIRO RAMOS, 1989; SERVA, 1997a; SERVA, CAITANO, SANTOS et al., 2015). Such a transition to action is conducted from the elements of pragmatist sociology, adopted in this study as a methodological and analytical resource of investigation (DODIER, 2005; BOLTANSKI and THÉVENOT, 2006; CEFAï, 2009).

\section{THE ANALYTICAL STARTING POINT: STUDIES ON RATIONALITY}

This study on phronesis is part of a line of studies on rationality in organizations, based on the contributions by Guerreiro Ramos (1989) and Serva (1997a, 1997b). The analysis of these studies in Brazil, prepared by Serva, Caitano, Santos et al. (2015), validated the propositions about the coexistence of different rationalities in organizations' management, considering the logic of instrumental and substantive action. Flyvbjerg (2003, p. 358) proposes phronesis as the action device that allows the individual to act and deliberate based mon different rational logic, according to the situation.

Aristotle was explicit in his regard of phronesis as the most important of the three intellectual virtues: episteme, techne, and phronesis. Phronesis is most important because it is that activity by which instrumental rationality is balanced by value-rationality, to use the terms of German sociologist Max Weber.

Phronesis is a capacity superior to reason itself is pointed out by Aristotle (1991, p. 145):

Practical wisdom, then, must be a reasoned and true state of capacity to act with regard to human goods [...] But yet it is not only a reasoned state; this is shown by the fact that a state of that sort may be forgotten but practical wisdom cannot.

In the pragmatic currents of French sociology, the authors use the concept of phronesis to explain how agents elaborate their justifications in the face of controversies. Initially, in Boltanski and Thévenot's (2006) approach to justifications, phronesis is the superior principle, abstracted from the notion of the common good in Aristotelian philosophy that allows actors, in moments of disputes and controversies, to act from different logics of argument and understand which expected action could produce a state of the common good.

Based on pragmatism, it is possible to prepare a proposition of the place of reason in human affairs and how agents use it to engage in their interactions (FREGA, 2012). In this sense, pragmatism removes the risk of the rationality approach to fall into transcendental abstractions, valuing the self-reflective dimension of experiences and actions. The rationality in pragmatist studies is found in how actors critique their own experiences, placing themselves at the base of capacity, in the control, and justification of their actions (FREGA, 2012; FREGA, 2006). Phronesis is, therefore, the capacity of agents to deliberate their actions based on purposes related to the common good. 


\section{Aristotelian phronesis}

Phronesis is the action of thinking, having common sense, prudence, and wisdom. Aristotle (1991) returns to the pre-Socratic Greek concept of phronesis, central in his discussions on ethics and human action (AUBENQUE, 2008). The Aristotelian emphasis on virtues as the core of moral life was disregarded in modernity and resumed in the last 40 years when numerous works developed the reflections on the concept of prudence. Influenced especially by Martin Heidegger, contemporary authors such as Hans-Georg Gadamer, Hannah Arendt, and Paul Ricouer have used phronesis to guide part of their discussions (FLYVBJERG, 2001, 2006; AUBENQUE, 2008).

In Aristotle (1991), practical wisdom (phronesis) corresponds to one of the virtues of the soul, as well as art (techne), scientific knowledge (episteme), philosophical wisdom (sophia), and intuitive reason (nous). Phronesis (prudence) is defined by Aristotle (1991) as an intellectual virtue of the practical man, capable of helping him to make the best decision in each context. This virtue deals with what is particular, variable, and therefore distinct from scientific knowledge, which deals with the 'universal' and 'invariable' (MACINTYRE, 1991). It differs from scientific knowledge based on the object of deliberation, "but it does not deliberate on necessary or immutable things, as these are the object of science. Practical wisdom would be the virtue of deliberating on what is contingent, and what is not the object of science" (AUBENQUE, 2008, p. 64, our translation).

Aristotle (1991) makes a clear distinction between the three possible forms of knowledge in his philosophy (Box 1).

Box 1

Types of knowledge

\begin{tabular}{|c|c|c|}
\hline TYPE OF KNOWLEDGE & DEFINITION & ACTIVITY \\
\hline $\begin{array}{l}\text { EPISTEME } \\
\text { Scientific knowledge }\end{array}$ & $\begin{array}{l}\text { Knowledge comes from observation with the } \\
\text { intent to learn. } \\
\text { Analytical rationality. }\end{array}$ & THEORY \\
\hline $\begin{array}{l}\text { TECHNE } \\
\text { Instrumental technical } \\
\text { knowledge }\end{array}$ & $\begin{array}{l}\text { Production activity focused on making artifacts } \\
\text { and utensils. } \\
\text { Practical and instrumental rationality. }\end{array}$ & POIESIS \\
\hline $\begin{array}{l}\text { PHRONESIS } \\
\text { Situational knowledge }\end{array}$ & $\begin{array}{l}\text { Determines in each case the appropriate mode } \\
\text { of behavior in concrete and real-life situations. } \\
\text { Deliberation on values. } \\
\text { Rationality about values or substantive } \\
\text { rationality. }\end{array}$ & PRAXIS \\
\hline
\end{tabular}

Source: Adapted from Escudero (2011) and Flyvbjerg (2003, 2006).

The distinction between scientific knowledge (episteme) and phronesis sparks a debate about the place of social sciences in this enclave. Such a debate is undertaken by authors like Flyvbjerg $(1998,2001,2003)$, who propose returning to phronesis as a research paradigm in the social sciences. For the author, the notions of contingency and context are often overshadowed by the scientific paradigm and the imperative of universality of cases. However, these elements are fundamental requirements for understanding social phenomena, including management. A similar proposition was highlighted by Koike and Mattos (2001), who question how knowledge in administrative theory considered only the episteme as a valid knowledge paradigm and led to the loss of the idea of phronesis at the level of erudite discourse.

Inspired by Flyvbjerg's $(2001,2003)$ arguments, Clegg $(2003$, p. 1) suggests that phronesis is the element capable of freeing the organization studies from the limitations of the field of rationality: "a central proposition of organization studies is that decision-making is always bounded in its rationality by the great depths and far reaches of uncertainty and ignorance within which it will always be constituted." For the author, as organizational theory is a science of subjects, it can only be understood from specific contexts of action, which would characterize organizational theory as an example of phronesis (CLEGG, 2006). 
The analysis of management situations proposed by Girin $(1996,2011)$, and the pragmatic analysis of action based on situations, as discussed by Quéré (1997), can help understand the context and situations as elements of phronesis. These authors present a perspective of analyzing social phenomena based on the centrality of the action, considering the works by Goffman (2001, 2008), which include the universe of prisons.

One of Aristotle's interpreters (1991), Aubenque (2008), suggests an understanding of phronesis from a vertical reflection of philosopher's work. The author identifies the prudent man (phronimos), the contingency of the world, the opportune time (kairós), the deliberation, the choice as the anthropology and cosmology of the constituent elements of phronesis. Aubenque's (2008) definition of phronesis is related to the contingency of the world, to the idea of an imperfect world, which is why it is a situational virtue. Thus, in the face of variable and unpredictable circumstances, the prudent man decides his action considering the notion of opportune time and the related context. The synthesis of the elements of Aristotelian phronesis interpreted by Aubenque (2008) offers some guiding elements to undertake the analysis of the object of study considered here.

\section{METHODOLOGY}

The research adopts a qualitative approach, presenting a case study conducted at the Complexo Penitenciário de Segurança Máxima de São Pedro de Alcântara (COPE) (a maximum-security prison in the Brazilian state of Santa Catarina). It was a cross-sectional and longitudinal study using data collected a) observing the organization's practices, b) through in-depth interviews, and c) via documentary analysis.

The observation of practices took a bottom-up view of pragmatist microsociology (VANDENBERGUE, 2006; CEFAï, 2009). The cross-sectional study occurred in 5 visits between January and March 2016. The field incursions were limited to the unit's operational conditions to offer visits accompanied by correctional officers. The in loco observations were conducted during the visits, covering different spaces and shifts of personnel. In addition to observation and questioning the duty staff, the researchers took photos to assist the analysis.

The collection and analysis of secondary data contributed to understanding the phenomenon, the organization's history, and how it has changed its practices. The data from internal documents, the complaint records made at the Public Ministry (MP), criminal cases, and news published in the local and national media, underwent analysis. This information subsidized a better comprehension of the interviews' content since the discourses often referred to the period of crisis that occurred between 2011 and 2014.

The narrative of the correctional officers' experience during the crisis was collected through semi-structured interviews, conducted with 15 officers working at the unit during the study period. Three of the interviewees were in charge of COPE management between 2010 and 2016.

Data collected during observation of the practices were triangulated with the interviews and the documentary analysis. In this sense, three levels of analysis were integrated: a) the macro level, analyzing the critical moments of the context; b) the meso level, based on the observation and analysis of the actions in the organization; and c) the micro-level, represented by the reflection on the experience lived by the correctional officers.

Phronesis was investigated from the following evidence: a) contingent events; b) time of action; and c) deliberation. These elements were highlighted during the data analysis. They form the synthesis leading to the research's conclusion. 


\section{DATA ANALYSIS: THE ORGANIZATION AND ITS PRACTICES}

COPE was founded in 2003 to meet a demand for prison vacancies in the Brazilian state of Santa Catarina. This maximumsecurity unit started to house the most dangerous inmates in the state, as well as detainees from other parts of the country. The unit has capacity for 1,056 inmates served by 150 correctional officers. It has exceeded the capacity since it opened, housing up to 1,190 exclusively male inmates ${ }^{2}$.

The organization's management has been historically conducted by retired police officers or by politically appointed personnel, and complaints of administrative misconduct, negligence, and mistreatment of inmates are frequent. The institutional crisis converged with the recognition of correctional officers as professionals in a different category from the police, subordinated to its own secretariat, the Secretariat of Justice and Citizenship (SJC). As a result, the state's prison units started to manage the resources from the Penitentiary Fund (FUPEN), and the professional category of correctional officers gained strength, starting to occupy management positions.

The change in the management profile established new work practices based on the officers' experience, especially in the fight against organized crime. In 2010, one of the first correctional officers to occupy the position of manager took over the unit after an institutional crisis and complaints to the MP, which involved cases of torture and administrative misconduct.

In addition to the institutional crisis, the inmates were exposed to the coordination of an interlinked and strong criminal group with high influential power. The Primeiro Grupo Catarinense (PGC) was a criminal faction formed from the combination of the most dangerous detainees in the state, who were transferred to COPE in 2003. In the previous years, the group used the negligent management and corrupted correctional officers to create its own rules and obtain privileges within the prison. The PGC began to impose its rules on detainees from other factions from Rio de Janeiro and São Paulo in the dispute for members and drug trafficking both inside and outside prisons.

The dispute between different factions resulted in an increase in the number of deaths within the unit and, subsequently, in an unprecedented public security crisis in the entire state of Santa Catarina, based on waves of urban violence in 2012, 2013 and $2014^{3}$.

The change in COPE's management practices is related to these events, and in this study, they are evidence of the phenomenon under analysis.

The following sections describe the main practices mapped in this research, which makes this a unique type of organization: a) "the key"; b) uniforms; c) cigarettes; d) visits; e) the wings; f) transfers; g) detainees' work; and h) health care.

\section{"Trabalho na chave" and the key to the prison}

Although prisons in Brazil can be seen as rational and planned institutions, as machines built to achieve officially determined and approved goals, their mission is, at the very least, contradictory: the punishment/segregation of inmates and, at the same time, their security and recovery. The daily practices in these organizations mirror such contradictions, which intensifies the contingency inherent in the human groups with whom it operates (GIRIN, 1996, 2011; GOFFMAN, 2001, 2008).

The officers' practices could be summarized in a framework of activities, forming the 'job description.' Based on the job description, the correctional officer would perform their routine, manage the due tasks, in an order previously established. This would be the reality if the assumptions of rational planning and execution were validated, considering a predictable demand. However, the officers act on a set of complex situations that involves the desires and needs of the inmates, with the emotional, psychological, and even physical risks that a prison can cause both to the inmates and those working in the system.

\footnotetext{
${ }^{2}$ Data from the INFOPEN report of the Ministry of Justice/National Penitentiary Department - Depen (BRASIL, 2017).

${ }^{3}$ The three consecutive public security crises in the state of Santa Catarina were coordinated by the action of the criminal faction PGC, a faction that was formed within the state's maximum-security prison complex. From inside the unit, inmates ordered more than 100 attacks in 33 cities in the state left 37 buses burned and a series of violent acts on the streets (CAITANO, 2016).
} 
The expression "trabalho na chave" (working with the keys) is used by COPE officers to characterize the activities involving the direct contact with inmates, such as opening, monitoring, and closing of cells with the consequent monitoring of the daily movement of detainees. Opening and closing doors (called "bater o cadeado," or, literally, 'hitting the lock'), is a repeated daily routine task for officers, often without apparent difficulties. However, when closing the doors, the correctional officer may face a serious contingency, such as finding an injured (or murdered) inmate, a fight between detainees, or being assaulted.

The contingencies associated with the officers' work at COPE were aggravated by the increase in organized crime within the unit. The criminal group PGC influenced and dictated which officer would be allowed to work in the tasks involving direct contact with inmates (trabalho na chave). Therefore, the faction guaranteed that officers who tried to enforce the rules, conducting the searches properly, seizing drugs, and objects of potential risk would never do trabalho na chave.

According to the correctional officers, during the period of the crises, "inmates had the keys of the prison in their hands." The management actions to reclaim control took place from 2011. These actions are the background of the practices analyzed in the following sections and were directly related to the crises that reached the entire state in the following years.

\section{Clothing and cigarettes as non-human elements of symbolic and economic power}

Until 2010, the state government did not provide uniforms and security equipment to officers, with the exception of weapons. They did not provide uniforms to inmates. The officers purchased vests, black clothes, and boots with their own resources. The officers searched for these items based on the symbolic goal of personification: clearly representing in the prison (especially in the large courtyard) who are the correctional officers. Also, in case of a rebellion, facilitating the quick distinction between officers and inmates (PICKERING, 2013, 2015). Among the incarcerated population, the absence of uniform made it possible to differentiate status: power was symbolized by the use of "branded clothes" by inmates:

\section{[...] the inmate sported expensive clothes, branded sneakers, you could see that the guy had an influence} there (Interviewee 9).

The ban on the entry of cigarettes touched a cultural and economic aspect in the unit.

The talk among the officers was that if you took away cigarettes, the prison would collapse. [meaning that inmates could start a rebellion] (Interviewee 9).

The law that prohibits cigarette smoking in closed environments came into force in the state in 2009. However, within the prison unit, the determination was not enforced, and there was, on the part of the officers, a certain fear that the withdrawal of cigarettes would cause insurgency.

Withdrawing cigarettes was an important means of weakening economic power since cigarettes fostered a "local business," overvalued by those who held power. The ban came about gradually, reducing the quantities allowed until total withdrawal. This process cooled the impact on the unit, but the measure directly challenged the interests of detainees who used the cigarette trade to demand favors.

The management, at that time exercised by correctional officers, acted on certain non-human elements reducing their symbolic power. This measure affected the factions' economic and political influence and revealed that more than observing the law, the managers made decisions using the knowledge based on their experience of the prison's daily life. The gradual elimination of cigarettes reveals the same experience-based knowledge. There is, therefore, evidence of phronesis, or practical wisdom as the basis of management actions in the face of adverse situations that had been maintained through crystallized practices over time.

\section{Visits: the link with the outside world and the prison thermometer}

Visits represent an important thermometer of the prison climate. Strong evidence of this is that family members are instructed by detainees not to attend visits when there is a threat of rebellion or an imminent uprising. The family has very limited contact, reduced to several fortnightly visits, eagerly awaited by the detainees. When there is an absence of visits to the prison, it gets the officers' attention because it implies a possible rebellion (GIRIN, 1996, 2011; QUÉRÉ, 1997). 
Family members play an essential role in the dynamics of organized crime, as they can greatly expand the communication network beyond the prison walls. Also, it is not possible to know for sure the dimension of such a network. Visitors make it possible for factions to act from inside the prisons, even in geographically distant units. In this sense, the territorial and spatial dimension has a preponderant role and demonstrates that the course of actions cannot always be determined in advance, but the actions materialize according to the situation (QUÉRÉ, 1997; RAULET-COSSET, 2008).

In this sense, the evidence of phronesis was perceived in advance of intelligence work within the unit, which brought together correctional and police officers. Although there is no appropriate system to link communication between these services, contact is often made through WhatsApp groups that integrate correctional and police officers, and enable communication and the exchange of information captured inside and outside the prison. The notion of opportune time, in this case, prevails over formal communication mechanisms and allows officers to preventively act when dealing with plans for rebellion, escapes, or death threats.

\section{A prison wing for each sentence}

The separation of inmates in different wings, based on the time they have to serve, was an important management measure adopted in the period analyzed. Previously, detainees with reduced prison sentences shared cells with prisoners sentenced to 20 or 30 years in prison. This disorderly allocation favored contact between the most dangerous prisoners with those who were already in a semi-open regime or with permission for temporary exits, that is, prisoners who already had "one foot out of jail”"4.

The random distribution of the inmates encouraged the growth of the factions, which started to dispute the detainees' adhesion:

[...] there were many prisoners joining the faction, I could see that based on their sentence [...] that's the problem, when you put a guy who got a low sentence with someone sentenced to more than 100 years (Interviewee 1).

However, the relocation faced a limiting factor: the lack of suitable places for different regimes:

[...] the inmate was in a closed regime and progresses to the semi-open regime. But as there are no vacancies in the semi-open, he remained in the closed regime waiting for a place (Interviewee 2).

The officers' efforts to separate prisoners among wings based on their sentences, also considering the types of crime committed, generated a great deal of movement in 2011, which was recorded in internal documents. In the perception of the former manager of the unit, this change weakened the faction's operations:

[...] the detainee who had the right to temporarily leave the prison was forced by the group to follow orders, under threat of being executed on his return (Interviewee 1).

Released from the so-called "cellmates support," the detainee could consider the advantages of not getting involved with the organized crime.

Although separation, according to the inmates' sentences, seems an obvious necessity, this measure was taken only after correctional officers took over the unit's management. The process of deliberating allocations did not depend on expanding the structure, but on the experience of officers to move detainees with similar sentences from one wing to the other.

The experience at COPE also led penal system managers in the state to abandon the projects of large prison complexes since these structures favored the concentration of highly dangerous detainees and the proliferation of organized crime. As a result, the most recent prison units in the state are designed with a maximum capacity of 300 inmates. They already have the appropriate and safe workspaces, and Santa Catarina started to invest in electronic monitoring devices ${ }^{5}$.

\footnotetext{
${ }^{4}$ Jargon to refer to prisoners who are about to be released because they served their sentence.

${ }^{5}$ By December 2019, 1,150 electronic monitoring devices (ankle bracelets) were in use throughout the state.
} 


\section{The internal transfer of detainees}

In 2011, eleven deaths were registered in just five months, which led the Public Ministry (MP) and the National Council of Justice (CNJ) to intervene in the unit to investigate. In at least eight cases, the death resulted from fights between rival factions, which led the officers to change practices of transfers between wings and cells. Each transfer started to be analyzed on a case-by-case basis, considering the inmate's affiliation to criminal factions, which were mapped and registered in the criminal information system (IPEN). This information, therefore, became decisive when evaluating transfers.

Transfers are part of the dynamics of prison work. Before this measure, they were systematic processes that did not involve an analysis of the inmates' records. The correctional officers, however, realized that the inmates' requests for transfer were meticulously coordinated among the criminal leaders, with the intention of sending messages, recruiting new members for the group, or killing other detainees 'sentenced' by the criminal faction. The new practice, therefore, interrupted such deviations, retaking control of transfers.

As one officer explains:

[...] the coexistence inside a cell can become unsustainable, any misunderstanding can make the coexistence between inmates unfeasible. Inmates in a cell need to peacefully coexist with the detainee arriving (Interviewee 3).

The issue pressuring the correctional officers is the legal responsibility for the safety and life of the inmates. Deciding on transfers in situations involving threat, for example, where a detainee refused to return to his cell:

[...] if I leave the detainee in the cell and he's dead in the morning [...] or I can change him to another cell, and what if he had been ordered to kill another inmate? (Interviewee 4).

In these cases, what has been observed is that the subject, in a moment of despair, threatened as to his own safety, can react unusually. This type of situation takes on a heterogeneous form based on the combination of different factors (QUÉRÉ, 1997). In any case, the officer is not individually oblivious to the safety of the inmate since the decision to keep or remove the detainee to or from a certain cell also calls into question the values over which the officer governs their own conduct. In COPE, in these situations, the officer has the discretionary power to deliberate and act.

The effort to map and record the detainees' affiliations to specific criminal groups in the system is part of a set of practices included and enforced due to the practical knowledge of correctional officers. Likewise, phronesis clearly manifests in situations where officers have the power to deliberate and act to transfer detainees in emergency situations. In these cases, time is a determining factor in the inmate's safety. The officer and the supervisor on duty have to decide based on their knowledge of the situation.

\section{The work of inmates in prison}

Prison work represents a benefit for most inmates: it reduces the time spent in prison and offers a salary in return. Therefore, the selection of detainees to work in the workshops that licensed private companies established inside the unit requires analysis of both criminological and of the psychosocial profile of the inmate.

This analysis is carried out by a committee formed by officers, psychologists, and social workers, selecting inmates able to work from a series of objective and subjective criteria. The job opportunity determines, for example, access to outside areas, the kitchen, or the use of knives and tools.

This type of assessment was conducted by the team, signed by a specialized professional, and sent to the criminal court. The process changed, and the assessment currently requires an authentication that represents the unanimous opinion of the committee instituted by the unit. This practice was adopted after an inmate who had his application rejected threatened the specialized professional (a psychologist) who signed the assessment:

[...] after she denied his application, the inmate wrote her name on the wall of a cell and a threat: "so and so, you are going to die" (Interviewee 8). 
The committee established to select and sign the assessment of the inmates' applications sent to the Court reduced the risk to the professionals. The committee created, emerges from the experience and practical wisdom of the officers, after the situation observed with the psychologist.

Among the inmates who work, some provide services to the prison unit itself, called "regalias." These inmates undertake activities in the kitchen, in the infirmary, cleaning, maintenance, etc. In the context of the daily interpersonal relationship between the officer and the detainee, officers perceive a "regalia" as trustworthy.

An interviewee explained the complexity of this relationship of trust referring to the inmate's past, authenticity, and the correctional officer's moral values:

[...] I always tell officers not to ask what they were convicted of, depending on the crime, they lie and break trust (Interviewee 11).

In practice, there is a kind of pact of coexistence between officers and "regalias" to keep the unit operating.

By recommending that officers be unaware of the inmate's conviction, the interviewee, with more than 20 years experience, demonstrates a clear deliberation based on phronesis. In the officer's perception, having this information could put the officer in a clash with moral values and generates judgment; therefore, a clash between rationality and necessary action.

At the limit of the clash of rationalities, practical wisdom becomes a way of overcoming the impasse, establishing grounds for deliberating on the action and instituting new practices, such as the committee and the maintenance of the trust relationship between officers and "regalias."

\section{Hospital and judicial escort}

Detainees are escorted whenever there is a medical emergency or when they must appear in court. The court escorts were reduced with the use of videoconference; the expectation is that all judgments will be progressively carried out by video. However, health demands still involve contingency situations, such as psychotic outbreaks, suicide attempts, mutilations, or conditions that require hospitalization.

The unit has an outpatient care wing. However, in severe cases, the detainee is taken to hospital and permanently accompanied by an officer. The unpredictability of these events involves the risk of death to inmates and the responsibility of officers for external security. In this situation, there is evidence of contradiction that characterizes the mission of correctional officers, to which we have already drawn attention: the punishment/segregation of convicts and, concomitantly, their security.

The record of a suicide attempt in the duty report stood out during this study. The officer who handled the situation expressed indignation:

[...] I had to take him to corpus delicti exam and make a statement at the police station. On the way back, in the car, the guy took a razor from his pants and tried to kill himself again (Interviewee 4).

This fact illustrates the difficulties of the work team that operates directly on contingent situations and emotional, psychological, biological demands of the inmates (GIRIN, 1996, 2011; GOFFMAN, 2001). The work involves containing the innumerable suicide attempts of the inmates and maintaining a humanitarian standard of care (GOFFMAN, 2001, 2008).

A feature adopted in recent years at the unit was the use of cameras. This occurred when the officers' perceved the vulnerability of these cases, with the possibility of the officer being penalized and held responsible for the death of the detainee. In cases involving psychiatric emergencies, the situation is even more serious since the inmates tend to resist medication or undertake hospital care. 


\section{EVIDENCE OF PHRONESIS: AN EXIT IN ACTION TO THE LIMITS OF REASON}

The practical experience of correctional officers in dealing with organized crime typifies a phenomenon related to the context in which the organization and its officers are inserted. Organized crime and the mechanisms connecting these groups are part of a set of organizational phenomena neglected from the scientific point of view of management, as there are no studies that help to understand these processes. As the contingencies in prisons become more frequent and severe, to the point of impacting collective security, the phenomenon assumes the character of a public problem (GIRIN, 1996, 2011; CEFAï, 2009; DIAS, 2011).

The experience of correctional officers in prison management demonstrated the incorporation into organizational praxis of several practices, actions, and knowledge developed through the officers' experiences. According to the officers, the mechanisms that organized crime uses to dispute power within a prison involve a series of micro-dynamics that are hidden under the management perspective. For example:

[...] the small portion of detainees who can destroy a prison is not fighting for rights, but is disputing the entry of drugs, the death of members, the transfer of leaders to federal units (Interviewee 3).

This daily confrontation in critical situations expresses the elements of phronesis:

- The contingency of the situation, the appropriate time to act (opportune time), and the calculation and deliberation on the consequences (ARISTÓTELES, 1991; AUBENQUE, 2008).

These elements characterize the work in prisons as a prudential activity, which involves deliberate action on a universe of contingencies (FLYVBJERG, 2001, 2006; CHAMPY, 2018; DUBOIS, 2018).

Practical knowledge is observed in deliberations about routine situations such as regaining control via gradual symbolic actions. It is also observed in critical situations, in which the officer has the autonomy to deliberate, calculating the consequences and judging high-severity possibilities - for example, the risk of death of a detainee or the risk of transferring inmates. The analysis of the phenomenon highlights the incorporation/institutionalization of this practical wisdom (phronesis), in the management actions, many of which are pressured by opposite rationalities.

In this sense, the officer decides from his practical perception, in a calculated way, and at the appropriate time, about a contingent fact. Therefore, the deliberation of this action is not based on scientific or bureaucratic knowledge that comes from the rules, instructions, and procedures, but from phronesis (FLYVBJERG, 2006; AUBENQUE; 2008). Box 2 presents a synthesis of the analyzed situations that evidence the situational contingency, the opportune time for action, the deliberation, and the action incorporated in the management practices adopted by the correctional officers as new managers of COPE.

Box 2

Evidence of phronesis: identified situations

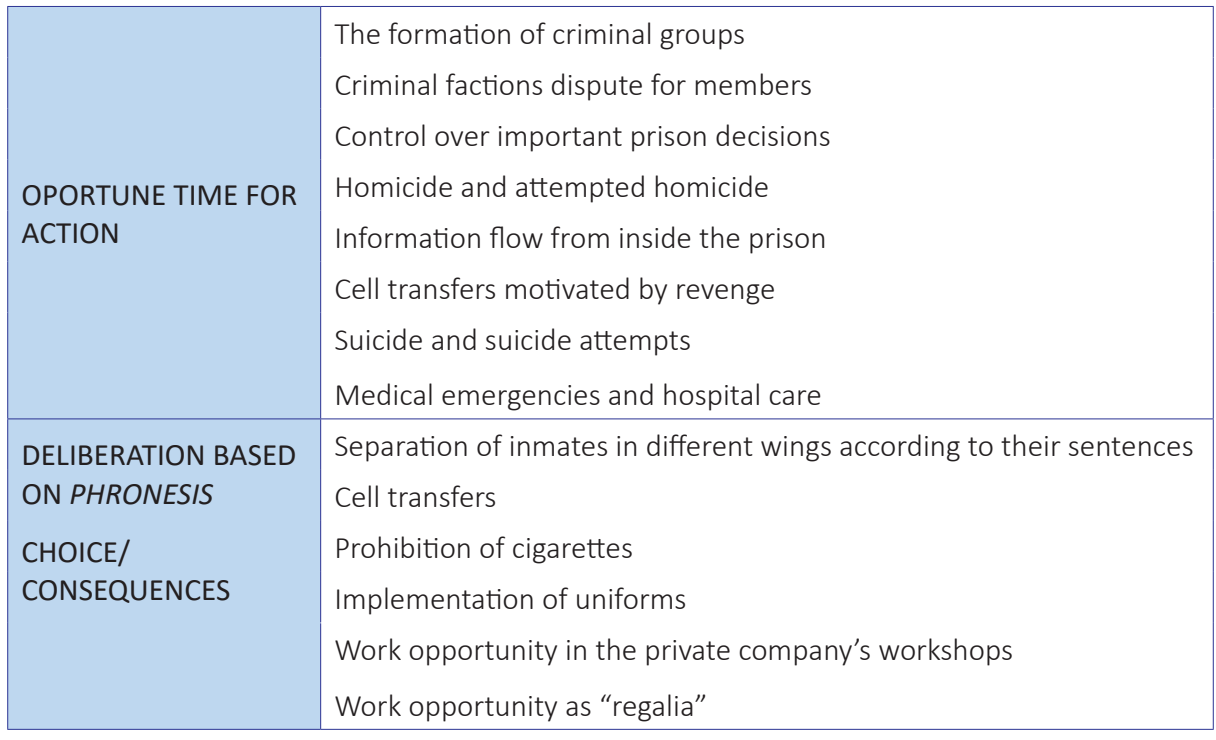

Source: Elaborated by the authors. 
Finally, the evidence raised in this study demonstrates how phronesis represents both an alternative to the one-sidedness of instrumental rational action and how to overcome the dilemmas and tensions experienced by the shock of rationalities in the context of a contingent world.

\section{FINAL CONSIDERATIONS}

The notion of phronesis illuminates a complete possibility of understanding the management practices of organizations confined and subjugated by the limits of instrumental rationality (CLEGG, 2003, 2006; AUBENQUE, 2008). Management theories, characterized by the relentless pursuit of prescription, standardization, and predictability, are not prepared to encompass the universe of phenomena related to subjects and the contingent uncertainties related to organizations (FLYVBJERG, 2001, 2006).

From the analysis of the case study, it is possible to say that human action in organizations, including management, manifests complex processes of intertwining rationalities. Practical wisdom, or phronesis, is a rational disposition mediating such intertwining. Therefore, in the dynamics of the management of a prison complex, this study identified elements that unveil this complexity, and express the elements of phronesis in contingencies and deliberate action, from the management situations in which the available technical or scientific knowledge is shown clearly insufficient.

What we found in this study is that the entire management experience of correctional officers who worked in the crises of confronting organized crime constituted a unique knowledge, inherent to the experience of this profession. This knowledge evidenced phronesis, a practical knowledge that comes from the officers' experience (FLYVJBERG, 2001, 2006; BOLTANSKI and THÉVENOT, 2006; AUBENQUE, 2008; FREGA, 2006, 2012).

These officers' experience in the face of the critical events that followed the growth of disputes among factions within the unit, produced a series of management practices. The prison system of Santa Catarina and its management practices generated at COPE are currently observed with interest by several other prison units in Brazil ${ }^{6}$. Many of the positive initiatives came from the perception of the officers in the unit, the first managed by correctional officers.

The contingencies related to the work of officers in the maximum-security complex caused effects on management and changes in work practices. These changes strengthened the professional category of correctional officers, and these workers are currently managing most of the prison units in the state. As a consequence of their effort and professional capacity, the person appointed to the position of State Secretary of Justice and Citizenship is a career correctional officer.

The experience of these professionals, previously limited to operational work, started to be legitimized based on management in times of crisis. The management practices mapped in this study are still operating, and new practices have been introduced from the perspective and knowledge originated from the officers' experience. The Academia de Administração Prisional $e$ Socioeducativa (ACAPS) (Academy of Prison and Socio-Educational Administration) is an institution that offers specialized training programs to professionals working in prisons. The academy teaches correct practices, acting in critical situations, prison intervention, and practices in case of rebellions, using simulations.

The practical experience of the correctional officers who reformed the prison's management and overcame the crises started to be institutionalized and taught in ACAPS programs as technical knowledge. ACAPS has trained groups of tactical intervention to meet the demands of federal prisons and units of other states in cases of mega-rebellions.

The immersion of correctional officers' practices and actions when facing the adverse environment inherited from previous management, and the reflection on the critical moments experienced in the present days have taught important lessons. Perhaps the most important is that a broader comprehension of the rationality in management could risk becoming static in the conceptual field of theoretical abstraction, and of the analysis restricted to mapping the individual's moral values. The findings of this research lead us to believe that, if knowledge of rationality in management is to expand, notably where

\footnotetext{
${ }^{6}$ The prison system in the state of Santa Catarina is considered a reference in Brazil in terms of the number of prisoners who work. The state was chosen by the Ministry of Justice to host the first and second Labor Exhibition of the Brazilian Prison System, in the years 2017 and 2018 , respectively.
} 
the subject can rationally make their decisions, the academic efforts must focus on the analysis of the action (FLYVBJERG, 2006; CLEGG, 2006).

Finally, concerning the theoretical discussion that inspired this investigation, we conclude that even if the subject ponders an instrumental or substantive rational logic, it is in the field of action that these aspects can be understood, providing effective contributions to the advancement of administration as applied social science.

This point characterizes what is understood in this study as the "limit of reason." 


\section{REFERENCES}

ADORNO, S. Exclusão socioeconômica e violência urbana. Sociologias, v. 4, n. 8, p. 84-135, 2002.

ADORNO, S. Políticas públicas de segurança e Justiça Penal. Cadernos Adenauer, v. 9, n. 4, p. 9-27, 2008.

ARISTÓTELES. Ética a Nicômaco: Poética. 4. ed. São Paulo: Nova Cultural, 1991.

AUBENQUE, P. A prudência em Aristóteles. São Paulo: Discurso Editorial, 2008.

BODÊ DE MORAES, P. R. Punição, encarceramento e construção de identidade profissional entre agentes penitenciários. São Paulo: Instituto Brasileiro de Ciências Criminais, 2005.

BODÊ DE MORAES, P. A identidade e o papel de agentes penitenciários. Tempo Social, v. 25, n. 1, p. 131-147, June 01, 2013.

BOLTANSKI, L.; THÉVENOT, L. On justification: economies of worth. Princeton, NJ: Princeton University Press, 2006.

BRASIL. Departamento Penitenciário Nacional - DEPEN. Sistema de Informações do Departamento Penitenciário Nacional SISDEPEN: População carcerária. 2017. Available at: <http://depen. gov.br/DEPEN/depen/sisdepen/infopen/relatorios-analiticos/SC/sc>. Accessed on: Feb. 05, 2020.

CAITANO, D. I. M. O. No Limite da Razão: a tensão, o deliberar e phronesis. Uma análise pragmática sobre situações críticas de gestão no trabalho dos agentes no complexo penitenciário do estado (COPE). 2016. Doctor Dissertation (Doctor Degree in Administration) - Universidade Federal de Santa Catarina, Centro Socioeconômico, Florianópolis, 2016.

CEFAÏ, D. Como nos mobilizamos? A contribuição de uma abordagem pragmatista para a sociologia da ação coletiva. Dilemas - Revista de Estudos de Conflito e Controle Social, v. 2, n. 4, p. 11-48. 2009.

CLEGG, S. Organizations: Power/History/Imagination. Cadernos EBAPE.BR, Rio de Janeiro, v. 1, n. 1, p. 22 a 34, Jan. 2003.

CLEGG, S. The bounds of rationality: power/history/imagination. Critical Perspectives on Accounting, v. 17, n. 7. 2006, p. 847-863.

CABRAL, S.; LAZZARINI, S. G. Impactos da participação privada no sistema prisional: evidências a partir da terceirização de prisões no Paraná. Revista Administração Contemporânea, Curitiba, v. 14, n. 3, p. 395-413, May/June 2010.

CHAMPY, F. The sociology of prudential activities: from collective commitment to social innovations. Sociologia, problemas e práticas, n. 88, p. 79-94, 2018.

CRUZ, M. V. G.; SOUZA, L. G.; BATITUCCI, E. C. Percurso recente da política penitenciária no Brasil: o caso de São Paulo. Revista de Administração Pública, Rio de Janeiro, v. 47, n. 5, p. 1307-1325, out. 2013.

DIAS, C. N. Estado e PCC em meio às tramas do poder arbitrário nas prisões. Tempo Social, v. 23, n. 2, p. 213-233, 2011.

DODIER, N. L'espace et le mouvement du sens critique. Annales HSS, v. 60, n. 1, p. 7-31, 2005.
DUBOIS, C. Prison Governors as Policymakers, Phronetic Practices as Enacted Knowledge. The Howard Journal of crime and justice, v. 57, n. 3, p. 363-378, set. 2018.

ESCUDERO, J. A. Heidegger, lector de la retórica aristotélica. Diánoia, v. 56, n. 66, p. 3-29, 2011.

FLYVBJERG, B. Rationality and power: democracy in practice. Chicago: University of Chicago Press, 1998.

FLYVBJERG, B. Making social science matter: why social inquiry fails and how it can succeed again. Cambridge: Cambridge University Press, 2001.

FLYVBJERG, B. Making organization research matter: power, values, and phrónesis. In: CZARNIAWSKA, B.; SEVÓN, G. (Ed.). The Northern lights: organization theory in Scandinavia. Stockholm: Liber, 2003. p. 370-387.

FLYVBJERG, B. Making Organization Research Matter: Power, Values, and Phrónesis. In: CLEGG, S. R. et al. (Eds.). The Sage Handbook of Organization Studies. 2. ed. Thousand Oaks: Sage, 2006. p. 370-387.

FÓRUM BRASILEIRO DE SEGURANÇA PÚBLICA - FBSP. Anuário Brasileiro de Segurança Pública 2013. 7. ed. São Paulo: FBSP, 2015.

FREGA, R. John Dewey et la philosophie comme épistémologie de la pratique. Paris: L'Harmattan, 2006.

FREGA, R. Practice, judgment, and the challenge of moral and political disagreement: a pragmatist account. Lanham: Lexington, 2012.

FREITAS, R. Reversões hierárquicas e eclosão de conflitos em prisões. Revista de Administração Pública, Rio de Janeiro, v. 19, n. 4, p. 27-37, 1985.

GIRIN, J. A linguagem nas organizações: signos e símbolos. In: CHANLAT, J. F. (Coord.). O indivíduo na organização: dimensões esquecidas. São Paulo: Atlas, 1996. v. 3. p. 23-66.

GIRIN, J. Empirical Analysis of Management Situations: Elements of Theory and Method. European Management Review, v. 8, n. 4. p. 197-212, 2011.

GOFFMAN, E. Manicômios, prisões e conventos. São Paulo: Perspectiva, 2001.

GOFFMAN, E. Estigma: notas sobre a manipulação da identidade deteriorada. Rio de Janeiro: LTC, 2008.

GUERREIRO RAMOS, A. A nova ciência das organizações: uma reconceituação da riqueza das nações. Rio de Janeiro: Ed. FGV, 1989.

KARAM, C. A. Legitimando uma inovação social: o caso do corpo de bombeiros voluntários de Joinville. Doctoral Dissertation (Doctor Degree in Administration) - Universidade Federal de Santa Catarina, Centro Socioeconômico, Florianópolis, 2014.

KOIKE, K.; MATTOS, P. L. C. L. Entre a epistêmê e a phrónesis: antigas lições para a moderna aprendizagem em administração. Perspectiva Filosófica, v. 7, n. 13, p. 179-193, 2001.

LEMOS, A. M.; MAZZILLI, C.; KLERING, L. R. Análise do Trabalho Prisional: um Estudo Exploratório. Revista de Administração Contemporânea, v.2, n.3, p. 129-149, set./dez. 1998.

LIMA, R. S.; BUENO, S. Introdução: o eterno presente da segurança pública brasileira. In: FÓRUM BRASILEIRO DE SEGURANÇA PÚBLICA 
- FBSP. Anuário Brasileiro de Segurança Pública 2015. 9. ed. São Paulo: FBSP, 2015. p. 8-9.

MACINTYRE, A. Justiça de quem? Qual racionalidade? São Paulo: Loyola, 1991.

MANSO, B.P.; DIAS, C. N. PCC, sistema prisional e gestão do novo mundo do crime no Brasil. Revista brasileira de segurança pública. São Paulo v. 11, n. 2, 10-29, ago./set. 2017.

PICKERING, A. Living in the material world. In: DEVAUJANY, F.; MITEV, N. (Eds.). Materiality and space: organizations, artefacts and practices. London: Macmillan, 2013. p. 25-40.

PICKERING, A. Science, Contingency and Ontology. In: SOLER, L.; TRIZIO, M.; PICKERING, A. (Eds.). Science as It Could Have Been: Discussing the Contingenty/Inevitability Problem. Pittsburgh: University of Pittsburgh Press, 2015. p. 117-28.

QUÉRÉ, L. La situation toujours négligée? Réseaux, n. 85, p. 163192, 1997.

RANGEL, F. M.; BICALHO, P. P. G. Superlotação das prisões brasileiras: Operador político da racionalidade contemporânea. Estudos de Psicologia, Natal, v. 21, n. 4, p. 415-423, 2006. Available at: <http:// ref.scielo.org/jrqd6f.> Accessed on: Feb. 02, 2020.
RAULET-CROSET. La dimension territoriale des situations de gestion. Revue française de gestion, Lavoisier, n. 184, p. 137-150, 2008.

SALLA, F. As rebeliões nas prisões: novos significados a partir da experiência brasileira. Sociologias, n. 16, p. 274-304, 2006.

SANTOS, L. S. et al. Razão e Administração: revisitando alguns elementos fundamentais. Cadernos EBAPE.BR, Rio de Janeiro, v. 17, n. 1, p. 37-48, dez. 2018.

SERVA, M. A racionalidade substantiva demonstrada na prática administrativa. Revista de Administração de Empresas, v. 37, n. 2, p. 18-30, 1997a.

SERVA, M. Abordagem substantiva e ação comunicativa: uma complementaridade frutuosa para a teoria das organizações. Revista de Administração Pública, Rio de Janeiro, v. 31, n. 2, p. 108-134, 1997b.

SERVA, M. et al. A análise da racionalidade nas organizações: um balanço do desenvolvimento de um campo de estudos no Brasil. Cadernos EBAPE.BR, Rio de Janeiro, v. 13, n. 3, p. 414437, 2015.

VANDENBERGUE, F. Construção e crítica na nova sociologia francesa. Sociedade e Estado, v. 21, n. 2, p. 315-366, 2006

Déris Oliveira Caitano

ORCID: https://orcid.org/0000-0002-0284-1546

Ph.D. in Administration; Researcher of the Research Center on Organizations, Rationality, and Development at Federal University of Santa Catarina

(ORD/UFSC), Florianópolis - SC, Brazil. E-mail: derisoliveira@gmail.com

\section{Maurício Serva}

ORCID: https://orcid.org/0000-0003-2416-3405

Ph.D. in Administration; Professor of Federal University of Santa Catarina (UFSC); Coordinator of the Research Center on Organizations, Rationality, and Development (ORD/UFSC), Florianópolis - SC, Brazil. E-mail: mauserva@gmail.com 